\title{
Bunderanthura bundera gen. et sp. nov. from Western Australia, first anchialine Leptanthuridae (Isopoda) from the Southern Hemisphere
}

\author{
Gary C. B. Poore ${ }^{1}$ and William F. Humphreys ${ }^{2}$ \\ ${ }^{1}$ Museum Victoria, PO Box 666, Melbourne, Victoria 3001, Australia. \\ Email: gpoore@museum.vic.gov.au \\ urn:Isid:zoobank.org:author:C004D784-E842-42B3-BFD3-317D359F8975 \\ 2 Western Australian Museum, 49 Kew Street, Welshpool, WA 6106; School of Earth and \\ Environmental Sciences, University of Adelaide, SA 5005; School of Animal Biology, University of \\ Western Australia, Nedlands, WA 6907, Australia. Email: bill.humphreys@museum.wa.gov.au \\ urn:Isid:zoobank.org:author:010A9975-91C7-4D13-B643-6E3B4BDF7233
}

\begin{abstract}
A new genus and species of leptanthurid isopod, Bunderanthura bundera, are described from a single individual from an anchialine environment in Western Australia. The new taxon differs from all species of Leptanthura in the elongate antennular and antennal peduncular articles (compact in Leptanthura), the presence of a strong thumb proximally on the palm of pereopod 1 (typically a square angle in Leptanthura), and on pereopod 2 (never seen in Leptanthura), an especially long pre-palm flexor margin on pereopod 3 (absent or short in Leptanthura), and a narrow uropodal exopod (few exceptions in Leptanthura). This is the first leptanthurid from non-marine environments outside the Atlantic.
\end{abstract}

KEYWORDS: Crustacea, isopod, Cape Range, stygobiont,new genus, new species

\section{INTRODUCTION}

Members of the crustacean suborder Isopoda have invaded fresh or brackish water many times. Representatives of freshwater taxa can be found among the Asellota (all species of Aselloidea in North America plus representatives of three other families), most Microcerberidea and Phreatoicidea, all Tainisopidea, some Oniscidea, occasional species of at least nine families of Cymothoida, plus few Idoteidae (Valvifera) and Sphaeromatidae (Sphaeromatidea) (Wilson 2008). Several species of Cyathura Norman and Stebbing, 1886 in the anthuroid family Anthuridae are found in brackish or fresh water (Frankenberg 1965; Negoescu 1981; Nunomura 1977; Poore and Lew Ton 1985) as are all 20 species of the related Stygocyathura (e.g. Andreev 1982a; Andreev 1982b; Botosaneanu and Sket 1999; Botosaneanu and Stock 1982; Nunomura 1992; Wägele et al. 1987). See Poore (2001) for lists of species. Among Paranthuridae, Cruregens fontanus Chilton, 1882 is interstitial in ground water in New Zealand (Wägele 1982) and the two Australian species of the three belonging to Cruranthura are estuarine (Poore 1984).

This is the first record of a stygobiont leptanthurid outside the Atlantic Ocean. The only other stygobiontleptanthurids known are four species of Curassanthura Kensley, 1981. Curassanthura halma Kensley, 1981, C. bermudensis Wägele and Brandt, 1985 and C. jamaicensis Kensley, 1992 live interstitially on West Indian beaches and C. canariensis Wägele, 1985 in the Canary Islands. All tolerate brackish water, records ranging from 18 PSU to fully marine.

\section{THE ENVIRONMENT}

The specimen was collected from Bundera sinkhole, an isolated anchialine sinkhole on the coastal plain of Cape Range, $1.7 \mathrm{~km}$ inland of the Indian Ocean coast where it experiences $10 \%$ of oceanic tidal range. It was collected by drawing a small plankton net though the 4-8 $\mathrm{m}$ interval water depth in the cave accessed through a bore hole. The salinity varied from 20.3 to 25.5 PSU, temperature $22.3-24.8^{\circ} \mathrm{C}, \mathrm{pH} 7.4-7.6$, and dissolved oxygen 1.04-2.52 $\mathrm{mg} \mathrm{L}^{-1}$ (determined using a Quanta-G, Hydrolab Corporation, Austin, Texas). The sinkhole overall exhibits marked ecohydrogeochemical stratification, especially at water depths of 8-18 m (Humphreys 1999; Humphreys et al. 2012; Seymour et al. 2007). 


\section{ASSOCIATED FAUNA}

The site is the main access to a rich anchialine (Stock et al. 1986) fauna including a core suite of species belonging to genera or higher taxa having a 'full Tethyan distribution' (Stock 1993: shown below with *) many of which are known elsewhere from Lanzarote (Canary Islands) and the Caribbean region (Humphreys 2000; Jaume and Humphreys 2001; Wilson and Humphreys 2001). The crustacean assemblage in these waters includes the remipede *Kumonga exleyi (Yager and Humphreys, 1996); the thaumatocypridid ostracod* Welesia kornickeri (Danielopol, Baltanas and Humphreys, 2000); the paracypridine candonid Phlyctenophora mesembria Wouters, 1999; the epacteriscid calanoid copepod *Bunderia misophaga Jaume and Humphreys, 2001; the pseudocyclopiid calanoid *Stygocyclopia australis Jaume, Boxshall and Humphreys, 2001; the ridgewayiid calanoid *Stygoridgewayia trispinosa Tang, Barron and Goater, 2008 the misophrioid copepod* Speleophria bunderae Jaume, Boxshall and Humphreys, 2001; the halicyclopine cyclopoids Halicyclops spinifer Kiefer, 1935 and H. longifurnatus Pesce, De Laurentiis and Humphreys, 1996; the laophontid harpacticoid Onychocamptus bengalensis (Sewell, 1934); the tetragonicipitid harpacticoid Phyllopodopsyllus wellsi Karanovic et al., 2001; ameirid harpacticoids Nitokra lacustris (Schmankevitsch, 1875), N. fragilis G.O. Sars, 1905 and Nitokra humphreysi Karanovic and Pesce, 2002; the atyid shrimps *Stygiocaris stylifera Holthuis, 1959, *S. lancifera Holthuis, 1959 and *Stygiocaris sp. undescribed (Page et al. 2008); the thermosbaenacean *Halosbaena tulki Poore and Humphreys, 1992; the hadziid amphipod *Hadzia branchialis (Bradbury and Williams, 1996); the melitid amphipod Nedsia douglasi Barnard and Williams, 1995 and the cirolanid isopod *Haptolana pholeta Bruce and Humphreys,1993.

\section{SYSTEMATICS}

\section{Family Leptanthuridae Poore, 2001}

\section{Bunderanthura gen. nov.}

\section{urn:Isid:zoobank.org:act:C19AA3C6-F194-4E3D-BDD5- 4D4FBDEB49DD}

\section{TYPE SPECIES}

Bunderanthura bundera sp. nov., herein designated.

\section{DIAGNOSIS}

Pereonite 7 about half length of pereonite 6. Pleonites 1-5 free and articulating; pleotelson with posterior margin of pleonite 6 indicated dorsally, delineated from telson. Eyes absent. Antenna peduncle articles longer than wide; flagellum elongate (of 9 articles), longer than last article of peduncle, articles cylindrical and free. Mandibular palp of 3 articles, palp article 3 with 3 terminal setae. Maxillipedal endite obsolete; palp one-third as long as basis, free from basis, with articles 1-2 fused, articles 3-5 minute and free. Pereopod 7 present. Pereopod 1 carpus, flexor margin with simple setae ; palm defined proximally by narrow thumb, palm with even marginal row of short complex robust setae along length, thumb bearing 1 robust seta. Pereopods 2 and 3 carpi flexor margins with slender flagellate seta and 2 simple setae. Pereopodal 2 propodus palm defined proximally by triangular thumb, palm with even marginal row of short complex robust setae along length, thumb with 2 robust setae. Pereopod 3 propodus longer than wide, palm oblique, with row of complex robust setae. Pereopods 4-7 carpi triangular, flexor margin with slender flagellate seta and 2 simple setae, enclosed anteriorly by surrounding articles; propodi elongate, flexor margin with flagellate setae. Uropodal exopod narrowly leaf-shaped, shorter than peduncle.

Male: unknown.

\section{REMARKS}

Bunderanthura most resembles Leptanthura Sars, 1897, a genus of 42 species and the largest genus of Leptanthuridae. Notable similarities are the presence of all seven pereonites and pairs of pereopods, free pleonites, differentiation of pereopods 2 and 3 from pereopods 4-7, all pereopods with triangular carpi, similar numbers of antennular and antennal flagellar articles, 3-articled mandibular palp, obsolete maxillipedal endite, and short maxillipedal palp with compressed distal articles. Bunderanthura differs from Leptanthura in the elongate first and second antennal peduncular articles (compact in Leptanthura), the presence of a strong thumb proximally on the palm of pereopod 1 (typically a square angle in Leptanthura), and on pereopod 2 (never seen in Leptanthura), an especially long pre-palm flexor margin on pereopod 3 (absent or short in Leptanthura), and with few exceptions a narrow uropodal exopod (broad and meeting in the middle in most species of Leptanthura).

Wägele (1989) believed Leptanthura to be a polyphyletic genus from which Bullowanthura Poore, 1978, Ulakanthura Poore, 1978 and Psittanthura Wägele, 1985[b] can be derived. It is not the intention or the place in this paper to undertake a cladistic analysis of this complex. All genera were said to share reduced maxillipedal endite and overlapping uropodal exopods (exopods secondarily smaller in few Leptanthura). All, except Leptanthura, have a reduced or no mandibular palp (also true of L. apalpata). Poore's (2001) phylogenetic analysis (that assumed these and all genera as monophyletic) was similar, recognising that these four genera shared the reduced maxillipedal endite, short maxillipedal palp and a robust seta on the margin of the carpus of pereopod 1. In his analysis, Leptanthura alone has about three terminal setae on 
TABLE 1 Distribution and habitat of stygobiont leptanthurid isopods.

\begin{tabular}{|c|c|c|c|c|}
\hline Species & Location & Salinity (PSU) & Habitat & Reference \\
\hline Curassanthura halma & $\begin{array}{l}\text { Curacao, West Indies, } \\
\text { Caribbean, west } \\
\text { Atlantic Ocean }\end{array}$ & $18-33$ & coral rubble & $\begin{array}{l}\text { Kensley 1981, 1992; } \\
\text { Wägele 1985a }\end{array}$ \\
\hline C. bermudensis & $\begin{array}{l}\text { Bermuda, west } \\
\text { Atlantic Ocean }\end{array}$ & $15.54-26.06$ & $\begin{array}{l}\text { anchialine: coarse } \\
\text { sediments in cave pool }\end{array}$ & $\begin{array}{l}\text { Wägele and Brandt } \\
1985\end{array}$ \\
\hline C. canariensis & $\begin{array}{l}\text { Lanzarote, Canary } \\
\text { Islands, east Atlantic } \\
\text { Ocean }\end{array}$ & $34-35$ & $\begin{array}{l}\text { anchialine: lava gravel } \\
\text { in Jameos del Agua } \\
\text { section of the Corona } \\
\text { lava tube, Lanzarote }\end{array}$ & $\begin{array}{l}\text { Wägele 1985a; } \\
\text { Wilkens et al. } 2009\end{array}$ \\
\hline C. jamaicensis & $\begin{array}{l}\text { Jamaica, Caribbean, } \\
\text { west Atlantic Ocean }\end{array}$ & 14 & $\begin{array}{l}\text { anchialine: } 1.5 \mathrm{~m} \text { deep } \\
\text { sinkhole, } 100 \mathrm{~m} \text { inland }\end{array}$ & Kensley 1992 \\
\hline Bunderanthura bundera & $\begin{array}{l}\text { Cape Range peninsula, } \\
\text { Western Australia, } \\
\text { Indian Ocean }\end{array}$ & $25.1-27.9$ & $\begin{array}{l}\text { anchialine: cave, } 1.7 \\
\text { km inland }\end{array}$ & this paper \\
\hline
\end{tabular}

the mandibular palp whereas the other genera have a uniarticulate palp or no palp at all. Some of the defining characters of the new genus are typical of hypogean species - attenuated limbs, reduced and narrow uropodal exopod, and reduced setation. Bunderanthura bundera may be like the others, derived from within Leptanthura sensu lato. All 42 species of Leptanthura are marine, ten are intertidal or subtidal but most are from shelf or bathyal environments (Müller 1992; Poore 2001).

Bunderanthura is superficially similar to species of Curassanthura from similar environments in the Atlantic (Table 1) but well-removed from Leptanthura in the cladistic analyses of Paranthuridae (sensu lato) (Wägele, 1989) and Leptanthuridae (Poore, 2001). While all share blindness and the attenuation of body and limbs associated with a hypogean environment, Curassanthura species lack pereopod 7, have elongate carpi on pereopods 2 and 3 , have a prominent maxillipedal endite, long (yet plesiomorphically fully articulated) maxillipedal palp, and lack robust setae on the pereopodal carpi. These are the characters that separated Curassanthura from Leptanthura and other genera in earlier cladistic analyses.

\section{ETYMOLOGY}

From Bundera, type locality and Anthura, a genus name commonly incorporated into generic names within Anthuroidea.

\section{Bunderanthura bundera sp. nov.}

Figures 1-3

urn:Isid:zoobank.org:act:A00DD04E-297D-4B22-A34FAB9BB8232A51

\section{MATERIAL EXAMINED}

\section{Holotype}

Australia: Western Australia: Exmouth Region, Bundera, Bore S1, $22.41235^{\circ} \mathrm{S}, 113.76517^{\circ} \mathrm{E}, \mathrm{R}$.A. Young and W.F. Humphreys, 29 June 2012 (stn BES17421), Western Australian Museum (WAM C52568, juvenile, total length $7.1 \mathrm{~mm}$, posterior section lost following dissection).

\section{DESCRIPTION}

Total length about 12 times width. Head as wide as its middorsal length, lateral lobes extending well beyond pseudorostrum. Pereonite 1-7 lengths with ratio 1:1.2:1.05:1.13:1.13:1:0.6. Pleonites 1-5 together as long as pereonite 7 middorsally, each with rounded epimera. Pleotelson 1.7 times as long as pereonite 7, 3 times as long as basal width of telson; telson parallel-sided 


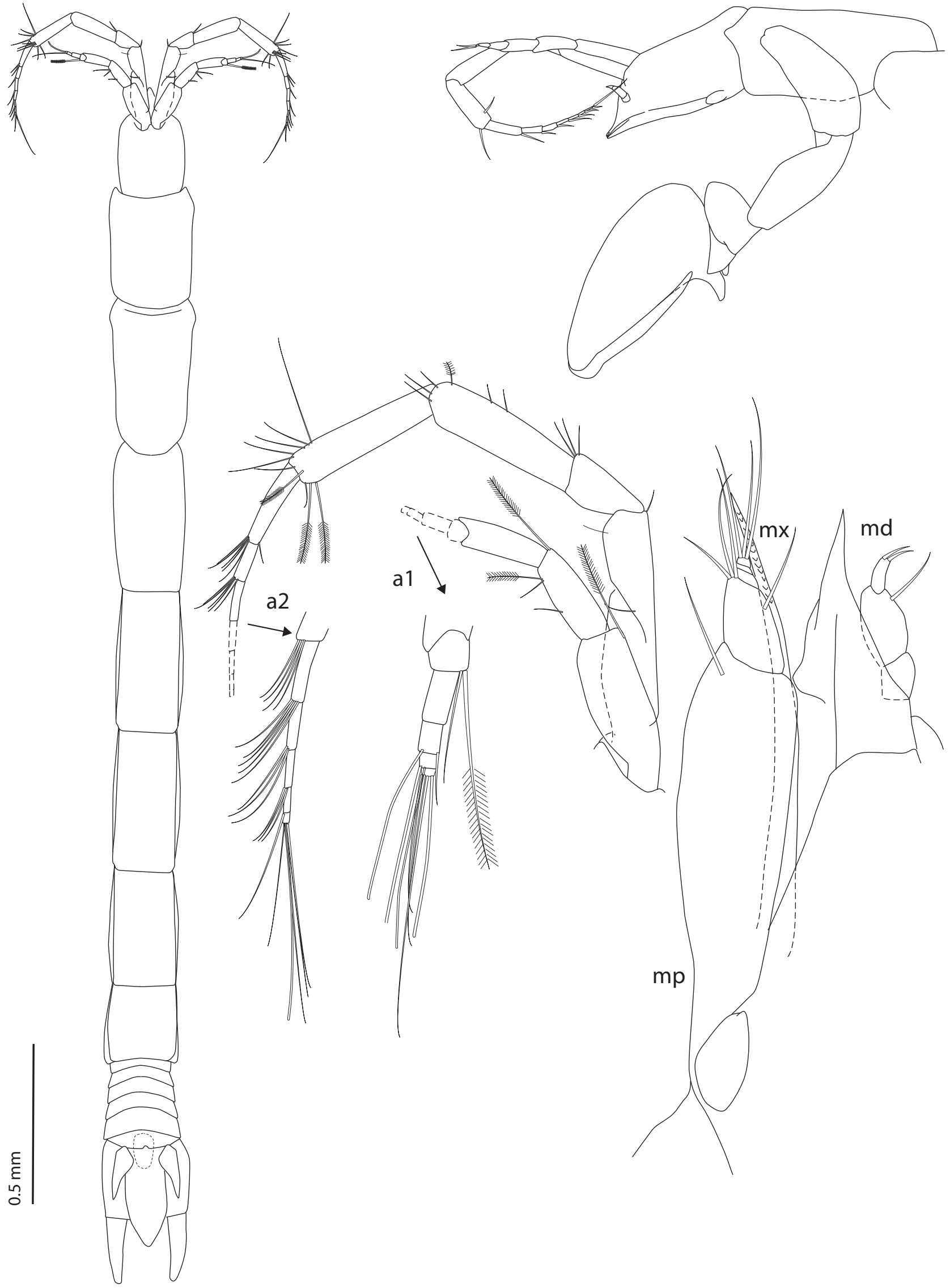

FIGURE 1 Bundanthura bundera gen. and sp. nov., holotype: Dorsal habitus, lateral view of head, pereonite 1 and pereonite 1. Left mouthparts in situ: mandible (md); maxillule style ( $\mathrm{mx})$, maxilliped (mp). Antennule (a1 with flagellum at greater magnification), antenna (a2 with distal flagellum at greater magnification) in situ. Scale bar refers to habitus only. 


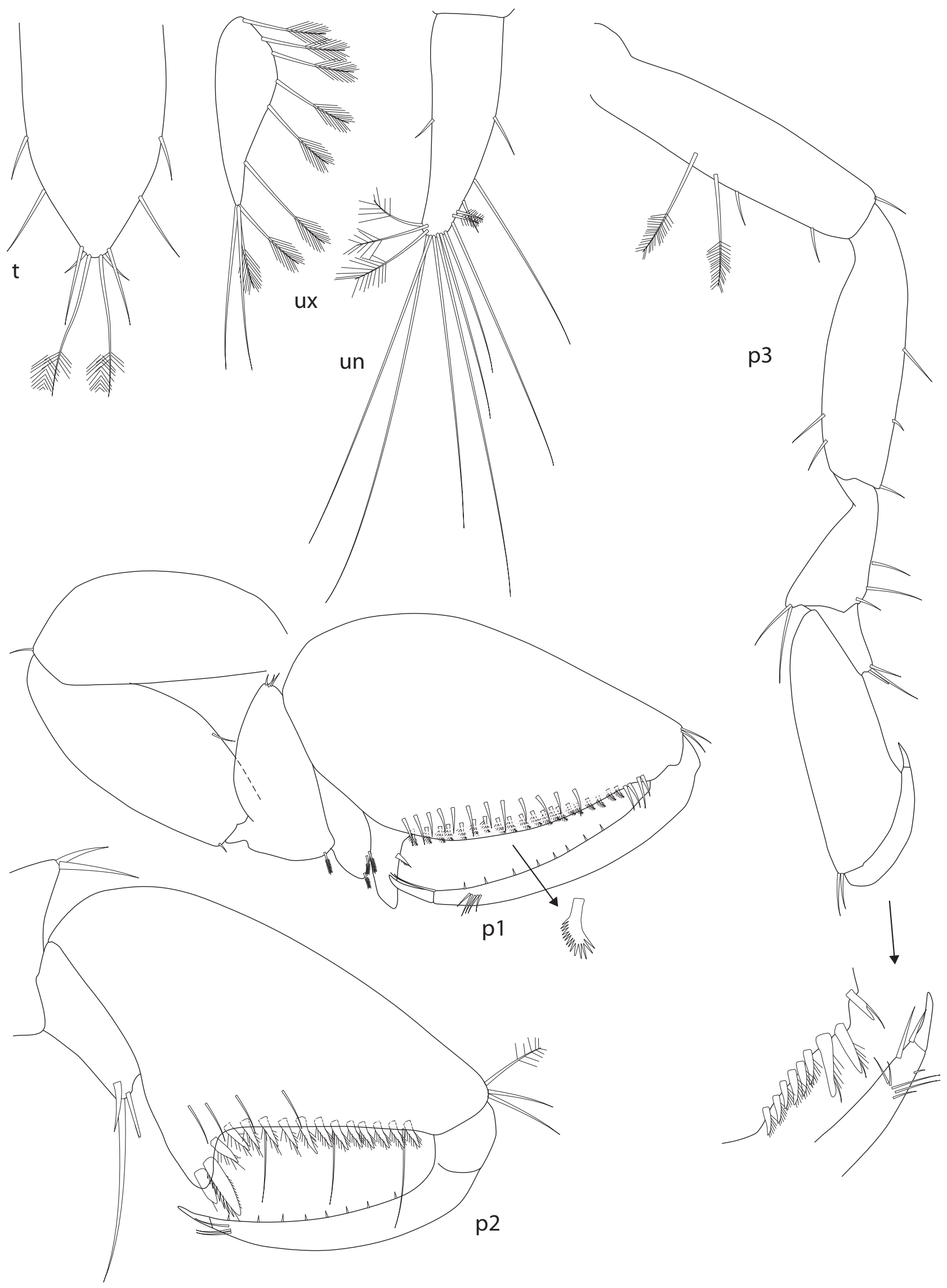

FIGURE 2 Bundanthura bundera gen. and sp. nov., holotype:Apex of telson (t); uropodal endopod and exopod (un, ux). Pereopods 1 (with lateral palm seta in detail), 2, 3 (with detail of propodal palm and dactylus apex). Pereopods to same scale, detail excepted. 


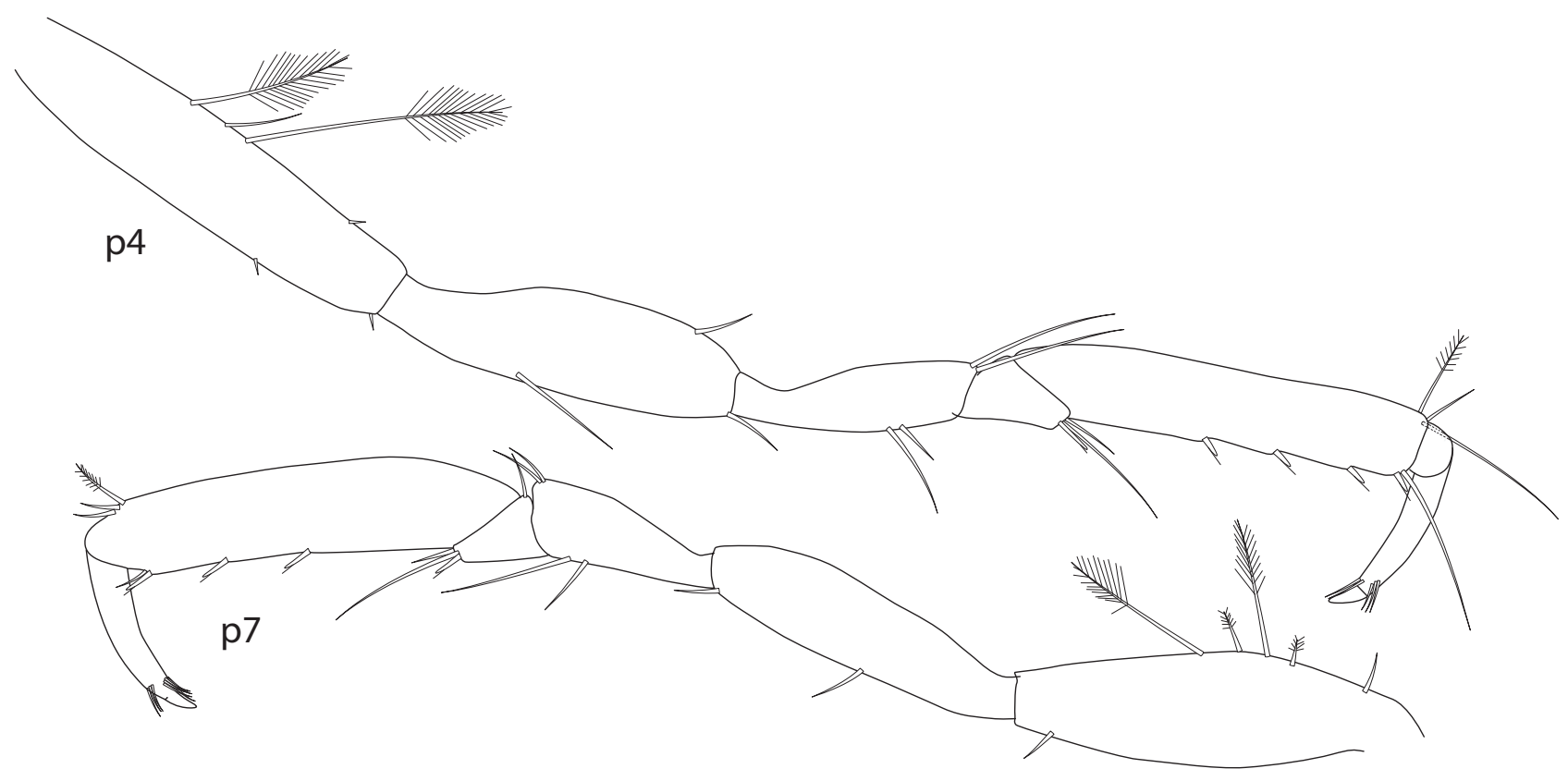

FIGURE 3 Bundanthura bundera gen. and sp. nov., holotype: Pereopods 4, 7 (to same scale as figure 2).

over proximal two-thirds, tapering with gently convex margin to acute apex over distal third, 3 pairs of long sublateral setae on distal third, apex with pair of simple and pair of plumose setae.

Antennule 1.5 times middorsal length of head; peduncle article 13 times as long as wide, article 20.4 length of article 1; article 3 as long as article 2; flagellum 0.7 length of peduncle article 3 , of short first article plus 4 articles bearing 3 setae and 4 aesthetascs. Antenna 3.6 times middorsal length of head; peduncle article 30.3 length of article 2; article 43.5 times as long as wide; article 54 times as long as wide, 1.1 times as long as article 4; flagellum 1.6 times as long as peduncle article 5 , of 8 diminishing articles. Mandibular palp article 2 with 1 subdistal seta; article 3 half length of article 2, tapering, with 3 short distal simple setae. Maxillule stylet acute, denticulate. Maxillipedal basis with 1 long distolateral seta, endite obsolete; palp article 1 tapering, with 1 mesiolateral seta, 3 distolateral setae; palp articles 2-4 minute, diminishing, with 3 distal setae.

Pereopod 1 merus wider than long, with 1 plumose seta on flexor margin; carpus visible only on flexor margin, with 3 plumose setae distally; propodus body 1.8 times as long as wide, strongly tapering, with narrow proximal thumb with 1 robust seta on distal margin ; palm with c. 20 short pectinate setae laterally and 12 simple setae mesially; dactylus tapering, closing on thumb, unguis about 0.2 length.

Pereopod 2 carpus set obliquely along flexor margin, with 1 slender flagellate seta and 2 simple setae on distal angle; propodus 2.5 times as long as basal width, tapering, with broadly-based proximal thumb bearing 1 flagellate robust seta and 1 strong pectinate seta; palm with 13 compact pectinate robust setae and 3 simple setae laterally, and 4 simple setae mesially; dactylus tapering, overlapping thumb.

Pereopod 3 merus triangular, 1.6 times as long as distal width; carpus set under proximal propodus, with 1 slender flagellate seta and 2 simple setae on distal angle; propodus 3 times as long as wide, dilating to oblique palm, with obtuse angle bearing 1 slender flagellate seta and 2 pectinate robust setae (no thumb); palm with 7 smaller pectinate robust setae; dactylus overlapping palm by more than length of unguis.

Pereopod 4 merus 3.5 times as long as greatest width; carpus triangular, with 1 slender flagellate seta and 2 simple setae on distal angle; propodus 5.5 times as long as wide, with 4 flagellate setae over distal $40 \%$ of palm; dactylus 0.4 propodus length.

Pereopod 7 merus 2.5 times as long as greatest width; carpus triangular, with 1 slender flagellate seta and 2 simple setae on distal angle; propodus 5.0 times as long as wide, with 3 flagellate setae over distal half of palm; dactylus 0.5 propodus length.

Uropod 1.25 times as long as telson; endopod 0.7 peduncle length, tapering, 3 times as long as wide, with 8 long distal simple setae and $3+2$ plumose setae; exopod 0.6 peduncle length, narrowly leaf like, 3 times as long as greatest width, with 6 marginal plumose setae, with 2 plumose and 2 long simple apical setae.

\section{ETYMOLOGY}

Bundera, from the type locality, noun in apposition.

\section{DISTRIBUTION}

Western Australia, Exmouth region, stygobiont, known only from type locality. 


\section{DISCUSSION}

Anchialine systems are noteworthy for their highly stratified water columns containing a diverse crustacean assemblage comprising numerous phylogenetic and biogeographic relicts (Iliffe 1992), attributes shared with Bundera sinkhole. The structure of part of the assemblage is highly predictable, even at the generic level, however far apart in the world they occur (Jaume et al. 2001; Wagner 1994), typically comprising atyid shrimps, thermosbaenaceans, hadziid amphipods, cirolanid isopods, remipedes, thaumatocypridid ostracods, and a vast array of copepods such as epacteriscid, pseudocyclopiid, and ridgewayiid calanoids, halicyclopine cyclopoids, speleophriid misophrioids, and superornatiremid harpacticoids. Furthermore, most of these higher taxa are restricted to the fully marine sections of anchialine systems or other subterranean habitats, having no known living marine members.

As noted by Wägele (1985a), the stygobiont members of the Leptanthuridae follow this tethyan distribution closely and the discovery of Bunderanthura bundera completes the 'full Tethyan track'. In addition, they all live in anchialine, or meso- to polyhaline habitats. There are, however, significant differences between the five stygobiont leptanthurids (Table 1) and the other taxa with full Tethyan distibutions. Firstly, B. bundera inhabits the non fully-marine section of the sinkhole whereas the core anchialine taxa occur only in fully marine waters below the zone of hydrogen sulphide in Bundera sinkhole (Humphreys 1999). Secondly, nonstygobiont leptanthurids are widespread in the oceans today where they are represented by 96 species (Poore and Bruce 2012), whereas the core Tethyan taxa are restricted to anchialine habitats. Finally, the stygobiont leptanthurids are absent from the North America plate, where the core anchialine taxa (Boxshall and Iglikowska 2012) are concentrated globally.

\section{ACKNOWLEDGEMENTS}

WH thanks Rae Young for her voluntary assistance on field work. The Defence Environment Department facilitated access to the area and funded the field work. Thanks also to Niel Bruce, Wolfgang Wägele and Buz Wilson for comments on the manuscript.

\section{REFERENCES}

Andreev, S. (1982a). Sur une nouvelle espèce cavernicole du genre Cyathura (Isopoda, Anthuridae), (Resultats Zoologiques de la Mission Speleologique Brittanique en Papouasie-Nouvelle Guinée, 1975, 7). International Journal of Speleology 12: 55-62.

Andreev, S. (1982b). Une Cyathura cavernicole nouvelle de Sarawak -Kalimantan du Nord (Isopoda, Anthuridae). Bulletin Zoölogisch Museum, Universiteit van Amsterdam 8: $149-155$.

Barnard, J.L. and Williams, W.D. (1995). The taxonomy of
Amphipoda (Crustacea) from Australian fresh waters, Part

2. Records of the Australian Museum 47: 161-201.

Botosaneanu, L. and Sket, B. (1999). A new freshwater stygobiotic species of Cyathura (Isopoda: Anthuridae) from Bohol Island, the Philippines. Acta Biologica Slovenica 42: 27-33.

Botosaneanu, L. and Stock, J.H. (1982). Amsterdam expeditions to the West Indian Islands, Report 17. Les Cyathura stygobies (Isopoda, Anthuridea) et surtout celles des Grandes et des Petites Antilles. Bijdragen tot de Dierkunde 52: $13-42$.

Boxshall, G.A. and Iglikowska, A. (2012). The composition of the genus Danielopolina Kornicker \& Sohn, 1976 (Mydocopa: Thaumatocyrididae). Natura Croatica 21 (Supplement 1): 15-16.

Bradbury, J.H. and Williams, W.D. (1996). Two new species of anchialine amphipod (Crustacea: Hadziidae: Liagoceradocus) from Western Australia. Records of the Western Australian Museum 17: 395-409.

Bruce, N.L. and Humphreys, W.F. (1993). Haptolana pholeta, sp. nov., the first subterranean flabelliferan isopod crustacean (Cirolanidae) from Australia. Invertebrate Taxonomy 7: 875-884.

Chilton, C. (1882). Notes on, and a new species of subterranean Crustacea. Transactions and Proceedings of the New Zealand Institute, Zoology 15: 87-92.

Danielopol, D.L., Baltanás, A. and Humphreys, W.F. (2000). Danielopolina kornickeri sp. n. (Ostracoda, Thaumatocypridoidea) from a western Australian anchialine cave: morphology and evolution. Zoologica Scripta 29: 1-16.

Frankenberg, D. (1965). A new species of Cyathura (Isopoda, Anthuridae) from coastal waters off Georgia, U.S.A. Crustaceana 8: 206-212.

Holthuis, L.B. (1959). Results of the reexamination of the type specimens of some species belonging to the subfamilies Pontoniinae and Palaemoninae (Crustacea Decapoda Macrura). Zoologische Mededelingen, Leiden 36: 193-200.

Humphreys, W., Tetu, S., Elbourne, L., Gillings, M., Seymour, J., Mitchell, J. and Paulsen, I. (2012). Geochemical and microbial diversity of Bundera Sinkhole, an anchialine system in the eastern Indian Ocean. Natura Croatica 21 (Supplement 1): 59-63.

Humphreys, W.F. (1999). Relict stygofaunas living in sea salt, karst and calcrete habitats in arid northwestern Australia contain many ancient lineages. In: Ponder, W.F. and Lunny D. (eds), The other 99\%. The conservation and biodiversity of invertebrates: 219-227. Royal Zoological Society of New South Wales, Mossman.

Humphreys, W.F. (2000). The hypogean fauna of the Cape Range peninsula and Barrow Island, northwestern Australia. In: Wilkins, H.K.A., Culver, D.C. and Humphreys, W. F. (eds), Ecosystems of the World: 581-601. Elsevier: Amsterdam.

Iliffe, T.M. (1992). Anchialine cave biology. In: Camacho, A.I. (ed.), The Natural History of Biospeleology: 614-636. Monografias del Museo Nacional de Ciencias Naturales: Madrid.

Jaume, D., Boxshall, G.A. and Humphreys, W.F. (2001). New stygiobiont copepods (Calanoida; Misophrioida) from 
Bundera Sinkhole, an anchialine cenote in north-western Australia. Zoological Journal of the Linnean Society 133: $1-24$.

Jaume, D. and Humphreys, W.F. (2001). A new genus of epacteriscid calanoid copepod from an anchialine sinkhole on northwestern Australia. Journal of Crustacean Biology 21: $157-169$.

Karanovic, T. and Pesce, G.L. (2002). Copepods from ground waters of Western Australia, VII. Nitokra humphreysi sp. nov. (Crustacea: Copepoda: Harpacticoida). Hydrobiologia 470: $5-12$.

Karanovic, T., Pesce, G.L. and Humphreys, W.F. (2001). Copepods from ground waters of Western Australia, V. Phyllopsyllus wellsi sp. nov. (Crustacea: Copepoda: Harpacticoida) with a key to world species. Records of the Western Australian Museum 20: 333-344.

Kensley, B. (1981). Amsterdam Expeditions to the West Indian Islands Report 10. Curassanthura halma, a new genus and species of interstitial isopod from Curaçao, West Indies (Crustacea: Isopoda: Paranthuridae). Bijdragen tot de Dierkunde 51: 131-134.

Kensley, B. (1992). New records of interstitial Anthuridea including Curassanthura, from the Western Atlantic (Crustacea: Isopoda). Stygologia 7: 187-192.

Kiefer, F. (1967). Cyclopiden aus Salzhaltigen Binnengewassern Australiens (Copepoda). Crustaceana 12: 299-302.

Müller, H.-G. (1992). A review of Leptanthura Sars, 1899, with description of new species from the Tioman Archipelago, Malaysia (Crustacea: Isopoda: Paranthuridae). Cahiers de Biologie Marine 33: 179-200.

Negoescu, I. (1981). New data about the fauna of anthuridean isopods isopods (Isopoda, Anthuridae) from the Libyan coast and the Suez Canal. Travaux du Muséum d'Histoire Naturelle "Grigore Antipa" 22: 401-420.

Norman, A.M. and Stebbing, T.R.R. (1886). On the Crustacea of the 'Lighting', 'Porcupine' and 'Valorous' Expeditions. Transactions of the Zoological Society of London 12: 77-141.

Nunomura, N. (1977). Marine Isopoda from Amakusa, Kyushu (I). Publications of the Amakusa Marine Biological Laboratory 4: 71-90.

Nunomura, N. (1992). Anthuridea (Crustacea: Isopoda) from the Ryukyu Archipelago. Bulletin of the Toyama Science Museum 15: 47-56.

Page, T.J., Humphreys, W.F. and Hughes, J.M. (2008). Shrimps down under: evolutionary relationships of subterranean crustaceans from Western Australia (Decapoda: Atyidae: Stygiocaris). PLoS ONE3(2): e1618. doi:1610.1371/journal. pone. 0001618.

Pesce, G.L., De Laurentiis, P. and Humphreys, W.F. (1996). Copepods from ground waters of Western Australia. 11. The genus Halicyclops (Crustacea Copepoda: Cyclopidae). Records of the Western Australian Museum 18: 77-85.

Poore, G.C.B. (1978). Leptanthura and new related genera (Crustacea, Isopoda, Anthuridea) from eastern Australia. Memoirs of the National Museum of Victoria 39: 135-169.

Poore, G.C.B. (1984). Colanthura, Califanthura, Cruranthura and Cruregens, related genera of the Paranthuridae. Journal of Natural History 18: 697-715.

Poore, G.C.B. (2001). Families and genera of Isopoda
Anthuridea. In: Kensley, B. and Brusca, R.C. Isopod systematics and evolution. Balkema: Rotterdam. Crustacean Issues 13: 63-173.

Poore, G.C.B. and Bruce, N.L. (2012). Global diversity of marine isopods (except Asellota and crustacean symbionts). PLoS ONE7 (8): e43529 doi:10.1371/journal.pone.0043529.

Poore, G.C.B. and Humphreys, W.F. (1992). First record of Thermosbaenacea (Crustacea) from the Southern Hemisphere: a new species from a cave in tropical Western Australia. Invertebrate Taxonomy 6: 719-725.

Poore, G.C.B. and Lew Ton, H.M. (1985). New species of Cyathura (Crustacea: Isopoda: Anthuridae) from estuaries of eastern Australia. Memoirs of the Museum of Victoria 46: 89-101.

Sars, G.O. (1897). Parts 3, 4. Anthuridae, Gnathiidae, Aegidae, Cirolanidae, Limnoriidae. In:An account of the Crustacea of Norway with short descriptions and figures of all the species: 41-80, plates 17-32. Bergen Museum, Bergen.

Sars, G.O. (1905). Pacifische Plankton-Crustaceen. (Ergebnisse einer Reise nach dem Pacific. Schauinsland 1896-1897.) II. Brack-wasser-Crustaceen von den Chatham-Inseln. Zoologische Jahrbücher Abteilung für Systematik 21: 371-414.

Schmankevitsch, V.I. (1875). [Some Crustacea of salt and freshwater lakes, and their relation to the surrounding environment.]. Zapiski Novoross Obshchestva Estestvoispytatelei 3(2): 1-391 [In Russian].

Sewell, R.B.S. (1934). A study of the fauna of the Salt Lakes, Calcutta. Records of the Indian Museum 36: 45-121.

Seymour, J.R., Humphreys, W.F. and Mitchell, J.G. (2007). Stratification of the microbial community inhabiting an anchialine sinkhole. Aquatic Microbial Ecology 50: 11-24.

Stock, J.H. (1993). Some remarkable distribution patterns in stygobiont Amphipoda. Journal of Natural History 27: 807-819.

Stock, J.H., Iliffe, T.M. and Williams, D. (1986). The concept 'anchialine' reconsidered. Stygologia 2: 90-92.

Tang, D., Barron, H. and Goater, S. (2008). A new genus and species of Ridgewayiidae (Copepoda: Calanoida) from subterranean waters of northwestern Australia. Journal of Crustacean Biology 28 551-556.

Wägele, J.-W. (1989). Evolution und phylogenetisches System der Isopoda. Stand der Forschung und neue Erkenntnisse. Zoologica (Stuttgart) 140: 1-262.

Wägele, J.-W., Coleman, O. and Hosse, U. (1987). Two new hypogean species of Cyathura from Melanesia (Crustacea, Isopoda, Anthuridea): further Tethyan relicts? Stygologia3: 89-106.

Wägele, J.W. (1982). The hypogean Paranthuridae Cruregens Chilton and Curassanthura Kensley (Crustacea, Isopoda), with remarks on their morphology and adaptations. Bijdragen tot de Dierkunde 52: 49-59.

Wägele, J.W. (1985a). On the Tethyan origin of the stygobiont Anthuridea Curassanthura and Cyathura (Stygocyathura), with description of Curassanthura canariensis n. sp. from Lanzarote (Crustacea, Isopoda). Stygologia 1: 258-269.

Wägele, J.W. (1985b). Two new genera and twelve new species of Anthuridea (Crustacea: Isopoda) from off the west coast of New Zealand. New Zealand Journal of Zoology 12: 363-423. 
Wägele, J.W. and Brandt, A. (1985). New west Atlantic localities for the stygobiont paranthurid Curassanthura (Crustacea, Isopoda, Anthuridea) with description of C. bermudensis n. sp. Bijdragen tot de Dierkunde 55: 324-330.

Wagner, H.P. (1994). A monographic review of the Thermosbaenacea (Crustacea: Peracarida). Zoologische Verhandelingen, Leiden 291: 1-338.

Wilkens, H., Parzefall, J. and Iliffe, T.M. (1986). Origin and age of the marine stygofauna of Lanzarote, Canary Islands. Mitteilungen aus dem Hamburgischen Zoologischen Institut und Museum 83: 223-230.

Wilson, G.D.F. (2008). Global diversity of isopod crustaceans (Crustacea; Isopoda) in freshwater. Hydrobiologia 595: 231-240.
Wilson, R.S. and Humphreys, W.F. (2001). Prionospio thalanji sp. nov. (Polychaeta: Spionidae) from an anchialine cave, Cape Range, northwest Western Australia. Records of the Western Australian Museum Supplement 64: 105-113.

Wouters, K. (1999). Two new species of the genus Phlyctenophora Brady, 1880 (Crustacea, Ostracoda) from the Indo-Pacific realm. Bulletin de l'Institut Royal des Sciences Naturelles de Belgique 69: 83-92.

Yager, J. and Humphreys, W.F. (1996). Lasionectes exleyi, sp. nov., the first remipede crustacean recorded from Australia and the Indian Ocean, with a key to the world species. Invertebrate Taxonomy 10: 171-187.

MANUSCRIPT RECEIVED 4 DECEMBER 2012; ACCEPTED 25 JULY 2013. 